\title{
The Effect of Hormonal Contraceptive on Low Birth Weight (LBW) Baby Delivery in Agronursing Area
}

\author{
Ira Rahmawati1 ${ }^{*}$, Dini Kurniawati², Yeni Fitria ${ }^{3}$ \\ 1,2Department of Maternity and Pediatric Nursing, Faculty of Nursing, University of Jember, Indonesia; \\ ira.rahmawati@unej.ac.id (Corresponding Author) \\ ${ }^{3}$ Department of Mental Health Nursing, Faculty of Nursing, University of Jember, Indonesia
}

\begin{tabular}{l}
\hline Article Info: \\
\hline Submitted: \\
03-11-2021 \\
Revised: \\
20-12-2021 \\
Accepted: \\
27-12-2021
\end{tabular}

DOI:

https://doi.org/10.53713/nhs.v1i3.85

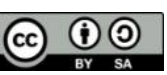

This work is licensed

under CC BY-SA License.

\begin{abstract}
Babies born with low birth weight (LBW) have a high risk and will have an impact on subsequent development. Studies show that the use of hormonal contraceptives can increase the risk of experiencing subjective health complaints than non-hormonal contraceptives. The study is an analytical descriptive study that aims to identify the effect of hormonal contraceptive used on low birth weight baby delivery. The study was conducted in three agricultural hospitals and three public hospitals in the Agriculture area of Besuki Residency. Data analysis of the sample was carried out by quota sampling. Characteristics of respondents were displayed by univariate analysis. The total number of participants in this study were 441 participants. Participants were divided into several data categories such as age, parity, medical history, previous history of preeclampsia, low birth weight babies, contraceptives used, complications of premature rupture of membranes. There two factors, that can predict the low birth weight baby delivery. They are hormonal contraceptives use and premature rupture of membranes. The test results get the hormonal contraceptive used factor to be the strongest factor (OR 19,12). Thus it was concluded "the hormonal contraceptive used factor is an abdominal factor of low birth weight baby delivery with a significance value of 0.000 (p0.05).
\end{abstract}

Keywords: low birth weight (LBW); babies; hormonal; contraceptives; agronursing

\section{INTRODUCTION}

The family planning program is one of the government programs to regulate the birth of children, the ideal distance and age to give birth, regulate pregnancy through promotion, protection, and assistance following reproductive rights to create a quality family (BKKBN, 2009). The implementation of the program is in the form of contraceptive services for the whole population of Indonesia (Liwang et al., 2018). The Contraceptive consists of hormonal and nonhormonal (Nasution et al., 2018). Most couples of childbearing age decide to use hormonal Contraceptive because it is easier, cheaper, and effective (Liwang et al., 2018). Studies show that there are more hormonal Contraceptive users among women of childbearing age (Nasution et al., 2018). Somehow, the best choice for contraception cannot be separated from the effects on long-term use (Jensen et al., 2016).

One of the effects that appear on the use of hormonal is excessive weight gain in women of childbearing age (Jensen et al., 2014). It is a sign that there are hormonal changes in estrogen in women of childbearing age (Jensen et al., 2014). There may be an effect on the baby's birth on the subsequent pregnancy. The baby's weight is normal if the birth weight is $>2500$ grams. The weight of the baby at birth is a determinant in determining the chances of survival, growth, and development of the baby (Susilowati et al., 2016).

Babies born with low birth weight (LBW) have a high risk and will have an impact on subsequent development, such as experiencing growth and development delays during childhood, being susceptible to disease, and even death because they have a smaller chance of survival (Setiati and Rahayu, 2017). Factors for the occurrence of LBW are due to maternal age, parity, premature rupture of the membrane (PROM), premature birth, history of preeclampsia, multiple pregnancy, previous history of LBW, fetus (congenital abnormalities), environment (Ratnasari et al., 2017). Environmental factors such as exposure to pesticides, exposure to cigarette smoke, and other toxic substances can increase the occurrence of premature births (Ratnasari et al., 2017). Pesticide exposure to pregnant women often occurs in agricultural environments where the majority of the population is farmers. 
The baby mortality rate in Indonesia is still very high, reaching 151,200 thousand people according to the 2017 IDHS and the dominant causes of infant mortality are LBW and premature (19\%) after asphyxia (21.3\%) (Kemenkes R1, 2019). In East Java, the incidence of baby mortality due to LBW was still very high in 2016; the incidence of LBW experienced a greater increase when than the previous year, which was (3.6\%) (Hartiningrum and Fitriyah, 2019). The incidence of low birth weight babies (LBW) in Jember was recorded as the district with the highest of LBW in East Java, with 1,586 cases in 2016 (Depkes Rl, 2017). Jember is an agricultural area where most of the area is tobacco farming. The study conducted in Arjasa Jember showed that pregnant women with low birth weight were exposed to pesticides (8\%) (Adila, 2019). However, other factors may cause LBW in newborns, such as maternal risk factors, such as a history of contraceptives.

Studies show that the use of hormonal contraceptives can increase the risk of experiencing subjective health complaints than non-hormonal contraceptives (Kusuma, 2016). Studies have shown that certain formulations of hormonal contraceptives can increase the risk of premature birth, weighing $<2500$ grams in subsequent pregnancies after the use of hormonal contraceptives (Jensen et al., 2015). Based on research, hormonal contraception methods are mostly used by housewives who live in agricultural environments, farmers, and traders with reasons of use based on their own experience and neighbors (Sari Priyanti and Syalfina, 2018). In addition, the advantages of hormonal contraceptives that can suppress pregnancy, there are various kinds of effects arising from the use of hormonal contraceptives in long-term use because the use of these methods can cause hormonal changes to the mother, so it is very likely to have an impact on subsequent pregnancies. Thus, preventive measures need to be taken. The role of nurses as health workers in facilitating couples of childbearing age to get healthy offspring and grow according to their stages of development.

The role of maternity nurses as educators and facilitators to facilitate couples of childbearing age can provide knowledge in determining safe and appropriate contraceptives. This is done to prevent the birth of babies with low birth weight caused by having a history of using the wrong Contraceptive. Therefore, the researcher is interested in writing an article about "The effect of hormonal contraceptive used on low birth weight baby delivery identify the effect of hormonal contraceptive used on low birth weight baby delivery identify the effect of hormonal contraceptive used on low birth weight baby delivery in the Agronursing area".

\section{METHOD}

The study is an analytical descriptive study that aims to identify the effect of hormonal contraceptives used on low birth weight baby delivery. The method involves medical records of high-risk mothers on pregnancy with low birth weight baby delivery before the COVID-19 pandemic. The study was conducted in three agricultural hospitals and three public hospitals in the Agriculture area of Besuki Residency. Data analysis of the sample was carried out by quota sampling. Characteristics of respondents were displayed by univariate analysis. The effect of factors that can cause low birth weight baby analyzed by regression test that include another factor like the previous history of preeclampsia, parity, and premature rupture of membranes.

\section{RESULT}

The total number of participants in this study was 441 participants. Participants were divided into several data categories: age, parity, medical history, previous history of preeclampsia, low birth weight babies, contraceptives used, complications of premature rupture of membranes, and Table 1.

Based on table 2, two factors can predict the low birth weight baby delivery. They are hormonal contraceptives use and premature rupture of membranes. The test results get the hormonal contraceptive used factor to be the strongest factor $(O R=19,12)$. Thus, it was concluded, "the hormonal contraceptive used factor is an abdominal factor of low birth weight baby delivery with a significance value of $0.000(p<0.05) "$. Table 1 . Frequency distribution of respondent characteristics based on age, parity, medical history, previous history of preeclampsia, low birth weight babies, hormonal contraceptives used, complications of premature rupture of membranes $(n=441)$. 
Table 1. Univariate Analysis

\begin{tabular}{lcc}
\hline Characteristic & Frequency & Percentage \\
\hline Age (years) & 31 & \\
$\quad<21$ & 333 & 7.0 \\
$21-40$ & 77 & 75.5 \\
$>40$ & & 17.5 \\
Parity & 241 & 54.6 \\
$\quad$ Primipara & 200 & 45.4 \\
$\quad$ Multipara & & \\
Previous Health History & 432 & 97.9 \\
$\quad$ No disease & 18 & 2.1 \\
$\quad$ Hypertension and diabetes Mellitus & & \\
Previous history of preeclampsia & 367 & 83.2 \\
$\quad$ No & 74 & 16.8 \\
$\quad$ Yes & & \\
Low birth weight babies & 204 & 46.3 \\
$\quad$ No & 237 & 53.7 \\
yes & & \\
Hormonal contraceptives used & 236 & 53.5 \\
$\quad$ No & 205 & 46.5 \\
$\quad$ Yes & & \\
Complications of PROM & 352 & 79.8 \\
$\quad$ No & 89 & 20.2 \\
$\quad$ Yes & &
\end{tabular}

Table 2. Results of multivariate regression analysis

\begin{tabular}{lcccccccc}
\hline & \multirow{2}{*}{ Coefficient } & \multirow{2}{*}{ S.E. } & \multirow{2}{*}{ Wald } & df & \multirow{2}{*}{ Sig. } & \multirow{2}{*}{ Exp (B) } & \multicolumn{2}{c}{ 95\% C.I. for EXP(B) } \\
\cline { 7 - 9 } & & & & & Lower & Upper \\
\hline Parity & 0,834 & 0,429 & 3,773 & 1 & 0.052 & 2.301 & 0.993 & 5.336 \\
Hormonal contraceptive & 2,951 & 0,482 & 37,420 & 1 & 0.000 & 19.116 & 7.427 & 49.199 \\
Constant & $-4,754$ & 0,497 & 91,585 & 1 & 0.000 & 0.009 & & \\
\hline
\end{tabular}

\section{DISCUSSION}

Mothers who have a history of using hormonal contraception are predicted to be at risk of having a baby with low birth weight in their next pregnancy. This is in line with previous research which revealed that the use of hormonal Contraceptives before pregnancy affected births in subsequent pregnancies (Hatch et al., 2017). Mothers who have a history of using hormonal contraception in pills (oral contraceptives) for a long time have a low birth weight (Hatch et al., 2017). Another study explained that the use of hormonal contraceptives with certain formulations of oral contraceptives can increase the risk of premature birth with birth weight $<2500 \mathrm{~g}$ (Jensen et al., 2015). The use of oral contraceptives with progestin formulations with norethisterone and desogestrel in the long term (> 12 months) has a positive relationship with premature birth (Jensen et al., 2014). Birth of LBW in subsequent pregnancies may occur due to physiological effects such as hormonal changes in the mother after discontinuation of oral contraceptives. Thus, couples of childbearing age who are planning to become pregnant in the future and want to use hormonal contraception need to be selective in choosing a safer formulation.

Studies show that hormonal Contraceptive is a contraceptive that is widely used among women who live in an agricultural environment (Sari Priyanti and Syalfina, 2018). One of the reasons most women of childbearing age use hormonal Contraceptives is that it is easy, cheap, effective, and efficient (Liwang et al., 2018). This is the advantage of hormonal contraceptives. Another study argues that women who use hormonal have a higher risk of experiencing vaginal discharge than other contraceptive methods (Sari Priyanti and Syalfina, 2018). Most of those who experience vaginal discharge are mothers who work as traders, farmers, and homemakers, and perhaps this is due to the lack of attention to cleanliness (Sari Priyanti and Syalfina, 2018). This is in line with studies that argue that one of the risk factors for LBW births is an infection in the mother, such as vaginal discharge (Setiati and Rahayu, 2017). Vaginal discharge caused by the use of hormonal contraceptives can be caused by hormonal changes in women (Nasution et 
al., 2018). However, there may be other factors that influence the incidence of LBW caused by the use of hormonal contraception (Habib et al., 2017). The use of hormonal contraceptives in a short time will show an effect on changes in female hormones (Liwang et al., 2018).

Active hormones during pregnancy are closely related to gestational age and fetal development (Cantonwine et al., 2013). The use of hormonal Contraceptives shows side effects such as excessive weight gain in women of childbearing age (Jensen et al., 2014). This is a sign that there is a change in the hormone estrogene in women of childbearing age (Jensen et al., 2014). There may be an effect on the birth of the baby in the next pregnancy.

The effect of hormonal Contraceptives on pregnancy after the release of hormonal contraceptives in the form of oral contraceptives affects the development of the fetus during pregnancy due to hormonal changes in the mother due to the influence of the formulation on oral contraceptives. In line with studies that pregnancy after long-term use of oral contraceptives is at risk of experiencing poor fetal growth and affects premature birth and disability (Charlton et al., 2016). Following the opinion about the formulation, dose, time of use of hormonal contraception, affects the growth and development of the fetus (Jensen et al., 2014). So it is important to pay attention to the selection of hormonal Contraceptives with appropriate and safe formulations for couples of childbearing age who are planning their next pregnancy. Hormonal contraceptives with a combination of progestin and norethisterone are very at risk for low gestational, premature birth with low birth weight (Jensen et al., 2014).

It is predicted that mothers who work in an agricultural environment with limited knowledge and economics pay less attention to the safe use of hormonal family planning. Habits that become a reference in choosing hormonal are the experiences of neighbors (Khayati and Sundari, 2019). Thus, there is a high risk of experiencing LBW births in the agricultural environment (Fajriana and Buanasita, 2018). However, there are other influencing factors, such as pesticide exposure in pregnant women in an agricultural environment. Another study revealed that not only maternal risk factors cause LBW births but also environmental factors (Chen et al., 2017). Environmental factors such as pesticide exposure in pregnant women can affect fetal growth and development (Larsen et al., 2017). This is in line with studies that reveal that pesticide exposure in pregnant women can increase the risk of having a baby with low birth weight (Jaacks et al., 2019). So that pregnant women in the agricultural environment need attention regarding the use of appropriate contraceptives and exposure to an unhealthy environment that triggers a high risk of LBW births. Predicted LBW births can also be caused by other factors such as parity, premature rupture of membranes (PROM), and a mother's history of preeclampsia (Habib et al., 2017). Therefore, other opinions are also important to be considered as preventive efforts in handling LBW births in the agricultural area.

\section{CONCLUSION}

The role of nurses in preventive efforts by providing appropriate education to couples of childbearing age in the agricultural area in determining the right choice of contraception is crucial, especially for couples who plan to undergo a subsequent pregnancy program after the use of hormonal family planning. Knowledge of couples of childbearing age in the agricultural area about contraceptive devices is expected to minimize the birth of babies with low birth weight so that they can create a healthy generation, grow and develop according to their stages of development to improve the quality of human resources in the future.

\section{ACKNOWLEDGEMENT}

Thanks to all the public hospitals in the Agriculture area of Besuki Residency

\section{REFERENCES}

Cantonwine, D. E., R. Hauser, \& J. D. Meeker. (2013). Bisphenol a and human reproductive health. Expert Review of Obstetrics and Gynecology. 8(4):329-335.

Charlton, B. M., D. Mølgaard-Nielsen, H. Svanström, J. Wohlfahrt, B. Pasternak, \& M. Melbye. (2016). Maternal use of oral contraceptives and risk of birth defects in denmark: prospective, nationwide cohort study. BMJ. 352(716):1-8.

Chen, S., R. Zhu, H. Zhu, H. Yang, F. Gong, L. Wang, Y. Jiang, B. Q. Lian, C. Yan, J. Li, Q. Wang, S. kun Zhang, \& H. Pan. (2017). The prevalence and risk factors of preterm small-for-gestational-age infants: a population-based retrospective cohort study in rural chinese population. BMC Pregnancy and Childbirth. 17(1):1-8.

Fajriana, A. \& A. Buanasita. (2018). Faktor risiko yang berhubungan dengan kejadian bayi berat lahir rendah di kecamatan semampir surabaya. Media Gizi Indonesia. 13(1):71.

Habib, M., C. Greenow, S. Ariff, S. Soofi, Abid Hussain, Q. Junejo, Amjad Hussain, F. Shaheen, \& K. Black. (2017). Factors associated with low birthweight in term pregnancies: a matched case-control study from rural pakistan. Eastern 
Mediterranean Health Journal. 23(11):754-763.

Hatch, E., K. Hahn, E. Mikkelsen, A. Riis, H. Sorensen, K. Rothman, \& L. Wise. (2017). Pre-gravid oral contraceptive use in relation to birth weight: a prospective cohort study. Euro J Epidemiologi. 176(3):139-148.

Jaacks, L. M., N. Diao, A. M. Calafat, M. Ospina, M. Mazumdar, M. O. S. Ibne Hasan, R. Wright, Q. Quamruzzaman, \& D. C. Christiani. (2019). Association of prenatal pesticide exposures with adverse pregnancy outcomes and stunting in rural bangladesh. Environment International. 133(October): 105243.

Jensen, E. T., J. L. Daniels, T. Stürmer, W. R. Robinson, C. J. Williams, D. Moster, P. B. Juliusson, K. Vejrup, P. Magnus, \& M. P. Longnecker. (2014). Maternal hormonal contraceptive use and offspring overweight or obesity. International Journal of Obesity. 38(10):1275-1281.

Jensen, E. T., J. L. Daniels, T. Stürmer, W. R. Robinson, C. J. Williams, K. Vejrup, P. Magnus, \& M. P. Longnecker. (2016). Hormonal contraceptive use before and after conception in relation to preterm birth and small for gestational age: an observational cohort study. BJOG. 176(1):139-148.

Khayati, Y. N. \& S. Sundari. (2019). Hubungan berat badan lahir dengan pertumbuhan dan perkembangan. Indonesian Journal of Midwifery (IJM). 2(2):58-117.

Larsen, A. E., S. D. Gaines, \& O. Deschênes. (2017). Agricultural pesticide use and adverse birth outcomes in the san joaquin valley of california. Nature Communications. 8(1):1-8.

Liwang, F., A. Bhargah, I. B. H. Kusuma, G. G. Prathiwindya, I. G. Indaya, S. Putra, \& L. S. Ani. (2018). Gambaran penggunaan kontrasepsi hormonal dan non hormonal di wilayah kerja upt puskesmas tampak siring 1. Jurnal Intisari Sains Medis. 9(3):41-46.

Nasution, W. M., F. A. Siregar, \& Asfriyanti. (2018). Pengaruh pemakaian kontrasepsi hormonal dan riwayat keluarga terhadap kejadian kanker payudara di rsud dr . pirngadi medan tahun 2017. Jurnal Medika Respati. 13(2):39-47.

Sari Priyanti \& A. D. Syalfina. (2018). Alat kontrasepsi dan aktivitas seksual sebagai faktor yang berpengaruh terhadap kejadian keputihan. Jurnal Berkala Epidemiologi. 5(September 2017):371-382.

Setiati, A. R. \& S. Rahayu. (2017). Faktor yang mempengaruhi kejadian bblr (berat badan lahir rendah) di ruang perawatan intensif neonatus rsud dr moewardi di surakarta. (Jkg) Jurnal Keperawatan Global. 2(1):9-20. 